\title{
Physicians Versus Administrators: A Perspective
}

\author{
Gurmeet Singh Sarla* \\ Department of General Surgery, Military Hospital, India
}

Submission: April 17, 2019; Published: May 08, 2019

*Corresponding author: Gurmeet Singh Sarla, Department of Surgery, Military Hospital, Devlali Cantt, Nasik, Maharashtra, India

\section{Introdution}

Is it a myth that physicians are poor man managers? Do we need to learn man management, store management, medical store management, and handling and maintenance of accounts? We need to compete with guys with MBAs and handle administrative issues as well as they do, if not better. We are not taught about administration in medical schools whereas they have a structured and well-defined course before they take over as Administrative heads of medical centers. A physician learns all the nuances of administration 'on the job'. It is high time we made an extra effort to learn administration as it is incredibly important in today's health services.

\section{Epidemiology}

Fifty four percent of physicians in the USA have a burn out problem for which they blame leaders involved in health care, finance, policy and clinical administration [1-3]. Physicians often state "Why don't these business people get us?". "Why doesn't the medical superintendent just back off and let me take care of my patients?" " Why are there so many Administrators when there are few medical care providers?"

\section{Pathophysiology}

The healthcare industry is changing rapidly and so is medical science. Relations between those who administer health care and those who deliver healthcare are strained. There is often a lack of understanding and mutual trust between the two.

\section{Treatment}

The Physician should be responsible for not only delivery of healthcare but improving healthcare delivery and redesigning healthcare as well. The Physician should be educated about healthcare policy, administration, finance and organizational behavior. Conversely, the Administrator should understand the clinician's perspective. Both should be able to speak the same language and build meaningful bridges.

\section{A good administrator knows that}

1. All good things flow from the Physician in the system.
2. Healthcare is a business and the Physician knows nothing about business and profits.

3. It is the Administrator who translates patient care activities into a profitable enterprise.

\section{Why are administrators paid so well?}

The mean salary per annum of an administrator with more than 10 years of experience in the USA is 600,000 USD whereas a physician with similar seniority and experience is paid about 280,000 USD. Financial management and credit control are major administrative problems in the USA, and it is the Administrator who sorts these problems out.

\section{Both the administrator and the physician have differ- ent perspectives}

This is what the Physician thinks: A hospital is not a hotel and patients should not expect to be pampered. This is what an Administrator thinks: Learn from the hospitality industry and treat patients like guests at a four-star hotel. So who is right? The Physician who practices tough love, or the Administrator who tries to emulate flight attendants and provide business class comfort to the patient.

\section{Results}

Some interesting studies have revealed that there is an inverse correlation between patient satisfaction and clinical outcome [4-7]. Patients can be very satisfied and dead an hour later. Interestingly, the Administrator tries to improve the patient satisfaction level whereas the Physician tries to improve the clinical outcome. So are they pulling in different directions?

\section{Clientele satisfaction versus clinical outcome}

Advise an MRI which was recommended by the patient's brother-in-law who practices medicine in the UAE or prescribe antibiotics which the patient just browsed on the internet and watch the patient satisfaction reaching new heights. Giving patients what they exactly want will score satisfaction points but is costly to the system and detrimental to the individual and public health. 


\section{What is the essence of quality healthcare?}

Quality healthcare is "the degree to which healthcare services for individuals and populations increase the likelihood of desired health outcomes and are consistent with professional knowledge". When the patients are dissatisfied, their real message is that their emotional needs are not being met. They may feel disrespected, confined, vulnerable, fearful and lonely. They expect the healthcare provider to treat these emotional needs too. To improve clinical outcome, we need to address these issues [8].

\section{The great healthcare bloat}

Between 1990-2012, the US healthcare force grew by $75 \%$, out of which $5 \%$ growth was contributed by physicians and the remaining $70 \%$ by administrative staff in the healthcare industry. The ratio of doctors to healthcare workers has gone from 1: 14 to 1: 16 . Out of these 16 healthcare workers, six are involved in patient care and the remaining 10 provide administrative support helping with documentation and meeting the regulatory requirements.

\section{The rise of the hospital administrator}

Doctors have become worker bees in the factory of administrative estates. In the past, the Physician was responsible for both business and practice of medicine and administrative personnel had complimentary roles to play. Today the Administrator has evolved into a kind of instruction manual dictating how, when and where the Physician should work. The Administrator has become the modern-day healthcare entrepreneur. In the USA the number of physicians has risen $150 \%$ over the last 30 years whereas the number of administrators has risen $3000 \%$. According to the New York Times, Hospital Administrator salaries are responsible for a higher percentage of medical costs8 According to the Times, health care administrative costs make up nearly $30 \%$ of the total U.S. health care bill.

Table 1: How are the Physician and Administrator different from each other?

\begin{tabular}{|c|c|}
\hline The Physician & The Administrator \\
\hline Idealism & Reality \\
\hline Trained to care for people & Trained to care for money \\
\hline Independent & Company man \\
\hline Fails to understand budgetary constraints & Faces political pressures and legal requirements \\
\hline Makes immediate, direct and efficient decisions & Has good communication skills, comprehends complex problems and produces efficient \\
solutions
\end{tabular}

\section{Approach of an administrator}

A smart administrator will lay off clerks, make the Physician maintain electronic health records of patients and take the calls of insurance companies thereby saving man power. He will try to automate the art of medicine through protocols and algorithms and will suggest cheaper and less trained alternatives in an attempt to cut costs. He will try to provide healthcare with the help of an army of IBM computers at the click of a button Table 1.

\section{Who is wrong?}

I was carrying a cup of coffee down a hospital corridor. I was grabbed by my shoulders and physically shaken up by a junior administrator. I was a 25-year-old intern coming off a 36-hour shift. He was 25 too, coming for his eight-hour working day.

\section{Who do patients really need?}

Patients need primary care but not necessarily a physician. Corporations undervalue physicians and consider them replaceable. They lay greater emphasis on employment of nursing practitioners and physician assistants.

\section{The Future}

In the future, physicians will not be judged by their clinical skills, but by how much money they saved for insurance companies and will be paid based on clinical outcomes. Everything will be target oriented: there will be a target cholesterol level, a target blood sugar level and even a target blood pressure reading which would determine the pay package of the Physician.

\section{Can a physician become a good administrator?}

A Physician never stops caring for his patients. A healthcare provider feels secure if he feels that his administrator understands his concerns and is focused on patient care.

Healthcare is about real people. It is an emotional arena in which the doctor- patient relationship continues to be of paramount importance.

\section{A call to action}

Medicine cannot survive and innovate without committed and compassionate physicians who should retake control of healthcare and practice as administrators. The physician in addition to looking after his patients, should take keen interest and learn about health policies, man management, procurement and purchase of medicines and accounting procedures. He should step out of his comfort zone of his department and actively involve himself in administration otherwise, as Arnold Schwarzenegger says, it will be "Hasta la vista, Docs".

\section{References}

1. Shanafelt TD, Boone S, Tan L, Dyrbye LN, Sotile W, et al. (2012) Burnout and satisfaction with work-life balance among US physicians relative to the general US population. Arch Intern Med 172(18): 1377-1385. 
2. Carol Peckham (2013) Medscape 2013 physician lifestyle report. Medscape Physician Lifestyle Report 28.

3. Carol Peckham (2017) Medscape Lifestyle Report 2017: Race and ethnicity, bias and burnout. Medscape Lifestyle Report.

4. Chang JT, Hays RD, Shekelle PG, MacLean CH, Solomon DH, et al (2006) Patients' global ratings of their health care are not associated with the technical quality of their care. Ann Intern Med 144 (9): 665672.

5. Fisher ES, Wennberg DE, Stukel TA, Gottlieb DJ, Lucas FL, et al. (2003) The implications of regional variations in Medicare spending, part 2: health outcomes and satisfaction with care. Ann Intern Med 138(4): 288-298.
6. Sequist TD, Schneider EC, Anastario M, Odigie EG, Marshall R, et al. (2008) Quality monitoring of physicians: linking patients' experiences of care to clinical quality and outcomes. J Gen Intern Med 23(11): 1784-1790.

7. Fenton JJ, Jerant AF, Bertakis KD, Franks P (2012) The cost of satisfaction: a national study of patient satisfaction, health care utilization, expenditures, and mortality. Arch Intern Med 172(5): 405411.

8. Norbeck TB (2013) Drivers of health care costs. A Physicians Foundation white paper-second of a three-part series. Mo Med 110(2): 113-118.

\section{Your next submission with Juniper Publishers will reach you the below assets}

- Quality Editorial service

- Swift Peer Review

- Reprints availability

- E-prints Service

- Manuscript Podcast for convenient understanding

- Global attainment for your research

- Manuscript accessibility in different formats ( Pdf, E-pub, Full Text, Audio)

- Unceasing customer service

Track the below URL for one-step submission https://juniperpublishers.com/online-submission.php 